\title{
Blueberry Bud Mite, Acalitus vaccinii (Keifer) (Arachnida: Acarina: Eriophyidae) ${ }^{1}$
}

H. L. Cromroy and L. C. Kuitert ${ }^{2}$

\section{Introduction}

The blueberry bud mite, Acalitus vaccinii (Keifer), was originally described by H.H. Keifer in 1939 from specimens collected in North Carolina and, at that time, was called Eriophyes vaccinii Keifer. However, in 1965 when Keifer erected the genus Acalitus, the mite was transferred to this genus based on its morphological characteristics. This mite has been reported on both cultivated and wild plants of the genus Vaccinium.

\section{Distribution}

A. vaccinii has been collected in Florida at Melrose and Palatka on commercial stands of blueberries.

\section{Description}

The blueberry bud mite is white, minute and about 200 microns or $1 / 125$ of an inch long. The mite lacks a foretibial seta which puts it in the genus Acalitus. Specifically, it has a shield pattern with a pair of obscure curved lines toward the rear center between the backward- directed shield setae. The female genital coverflap has longitudinal tubercles.

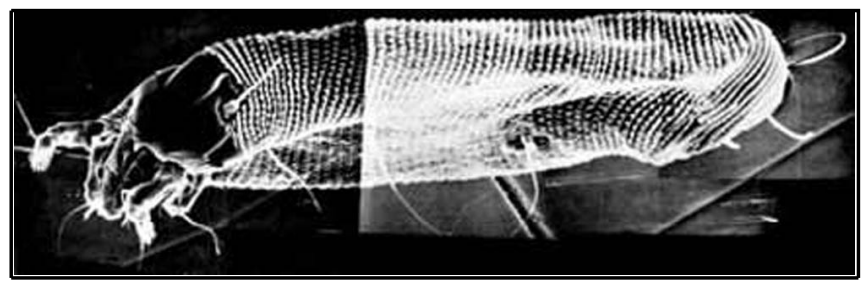

Figure 1. Dorsal-lateral view of the blueberry bud mite, Acalitus vaccinii (Keifer), using a scanning electron microscope. Credits: Division of Plant Industry

\section{Life History}

There is little known on the life history of this mite in Florida. The semitropical conditions in the state would seem to indicate that the mite does not have an overwintering female as in North Carolina.

\section{Hosts}

To date this mite has been taken on the commercial varieties of blueberry -- 'Tifblue' and 'Woodard', as well as several new cultivars. Based on typical injury, no variety appears to be immune to bud mite attack.

1. This document is EENY-186 (originally published as DPI Entomology Circular 130, updated for this publication), one of a series of Featured Creatures from the Entomology and Nematology Department, Florida Cooperative Extension Service, Institute of Food and Agricultural Sciences, University of Florida. Published: January 2001. This document is also available on Featured Creatures Website at http://creatures.ifas.ufl.edu. Please visit the EDIS Website at http://edis.ifas.ufl.edu.

2. H. L. Cromroy, professor emeritus, and L. C. Kuitert, professor emeritus, Entomology and Nematology Department, University of Florida, Gainesville, FL.

The Institute of Food and Agricultural Sciences (IFAS) is an Equal Employment Opportunity - Affirmative Action Employer authorized to provide research, educational information and other services only to individuals and institutions that function without regard to race, creed, color, religion, age, disability, sex, sexual orientation, marital status, national origin, political opinions or affiliations. For information on obtaining other extension publications, contact your county Cooperative Extension Service office. Florida Cooperative Extension Service / Institute of Food and Agricultural Sciences / University of Florida / Larry R. Arrington, Interim Dean 


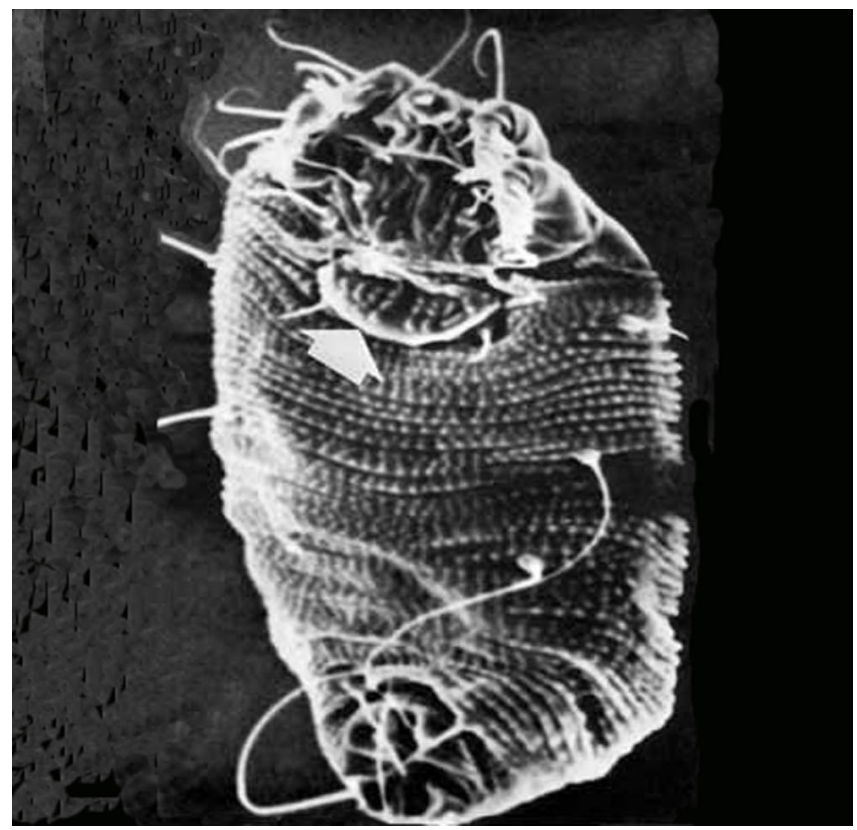

Figure 2. Ventral view of a female blueberry bud mite, Acalitus vaccinii (Keifer). Arrow points to genital flap with longitudinal tubercles. Distortion produced by vacuum treatment of mite. Credits: Division of Plant Industry

\section{Economic Importance}

It was estimated by one grower in Melrose that over $60 \%$ of his crop was lost as a result of mite and thrips damage. This mite attacks the buds which become closely packed or rosetted on the stem and then fail to expand and bloom. This results in berry and leaf loss. Keifer stated that mite feeding caused an unnatural succulence and epidermal roughening or blistering at the base of the fruit bud scales, causing them to hang in a tight rosette at the base of the fruit stem. Affected berries appear roughened and malformed. Also, the base of the fruit stem usually is blistered, retaining the juvenile red color or growing vacciniaceous tissue. In North Carolina, the rosetting is accompanied by fruit roughening or deformation of the entire cluster, while in Georgia it is reported not only that fruit clusters are deformed, but that retarded leaf growth also occurs. In Florida, our observations indicate that bud loss is the prime damage from mite feeding.

\section{Management}

Effective control is extremely difficult since the mites are protected by the bud scales. It is essential that sprays be applied at fairly high pressure (150 to $200 \mathrm{psi}$ ) and high gallonage to obtain effective

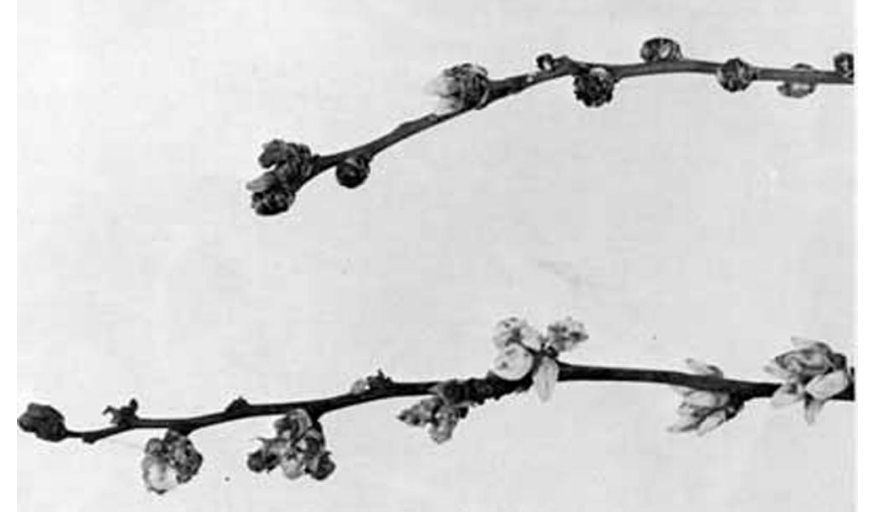

Figure 3. Blueberry buds infested by the blueberry bud mite, Acalitus vaccinii (Keifer) - TOP; uninfested buds BOTTOM. Credits: Division of Plant Industry

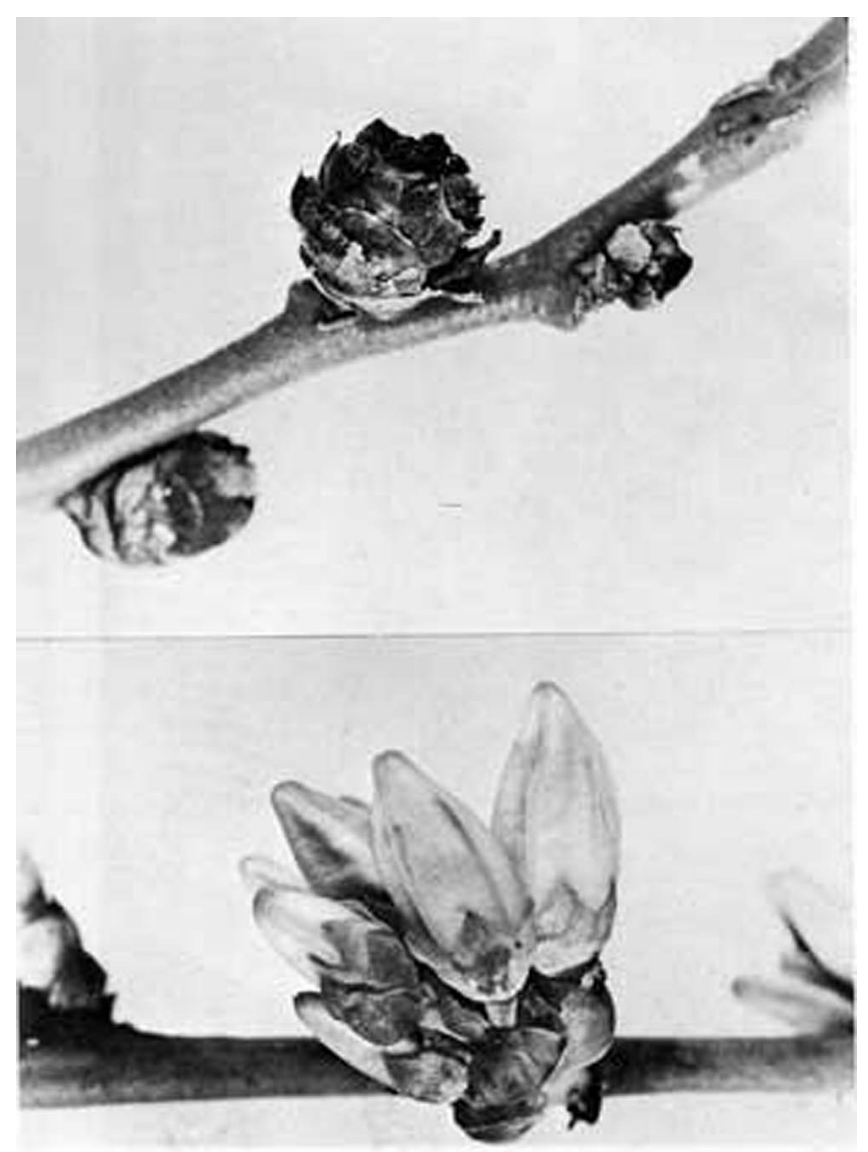

Figure 4. Blueberry bud infested by the blueberry bud mite, Acalitus vaccinii (Keifer) - TOP; uninfested bud bloom - BOTTOM. Credits: Division of Plant Industry

coverage and penetration. Timing of the application is important but poorly understood under Florida conditions.

For additional information see Insect Management Guide for Blueberries (http://edis.ifas.ufl.edu/IG070). 


\section{Selected References}

Keifer, H.H. 1939. Eriophyid Studies V. Bull.

Calif. Dept. Agric. 28: 329.

Keifer, H.H. 1941. Eriophyid Studies XI. Bull.

Calif. Dept. Agric. 30: 192-204.

Keifer, H.H. 1965. Eriophyid Studies B-14.

Calif. Dept. Agric., p. 2. 